\title{
Why Most African Countries are Poor
}

\section{Julius Ofori Kwasi*}

Department of Social Science, Kwame Nkrumah University of Science and Technology, University in Kumasi, Ghana

Keywords: Poor; Economic; Investment; Languages; Management; Social; Corruption.

\section{Introduction}

Africa remains a key territory on the global map, world's second largest and second most populous continent. It hosts a lot of ethnicities, culture diversities and considered by most paleoanthropologists as the oldest inhabited territory on earth. Rich in oil and natural resources, the continent holds a strategic position. It is the world's fastest-growing region for foreign direct investment, and it has approximately 30 percent of the earth's remaining mineral resources. It is home to more than 40 different nations and about 2,000 languages. The continent's resource extraction history is not encouraging. A country's natural resources, such as oil, gas, metals and minerals, belong to its citizens. Extraction of these resources can lead to economic growth and social development. However, poor management of natural resource has often led to corruption and conflict. The region is full of promise and untapped riches from oil and minerals and land to vast amounts of people capital yet, it has struggled since colonial times to truly realize its potential. This paper seeks to point out the reasons most of the African countries are poor.

\section{Africa-Poverty Nexus/Link}

Institution is the systems of established and prevalent social rules that structure social interactions. Language, money, law, systems of weights and measures, table manners, and firms (and other organizations) are all Institutions" [1]. Institutions are the "rules of the game" that emerge from formal laws, informal norms and practices, and organizational structures in a given setting. The incentives these institutions create shape the actions of public officials. Institutions can be conceptualized as guidelines for human actions, or the "logic of appropriate" behaviour in society. Jepperson [2] defines institutions as "those social patterns that, when chronically reproduced, owe their survival to relatively self-activating social processes." People tend to believe that there is a fundamental rationale for these patterns' existence (Figure 1).

Institutions in most African countries are weak which is accelerated by corruption among public/government officials. Public officials in these countries try to channel wealth belonging to these countries into offshore/foreign accounts for the benefit of themselves and their families. Because of weak institutions and poor tax base, these countries are not able to invest in police, transport, education and health etc. Some corruption practices in these countries are due to clan base thinking which does not allow themselves access to intelligent and talents of the whole population. It is difficult for the majority of the population in these countries to escape the poverty, when government money is used improperly [3,4].

In the jurisdictions of these countries, bribes, fraud and tribal favouritism are common within the all levels of government, which hampers any attempt to improve conditions across the countries.

Culture is the way of life of people living in a particular jurisdiction or area. This includes the characteristics and knowledge of a particular group of people, language, religion, cuisine, social habits, music and arts. Culture also involves shared patterns of behaviours and interactions, cognitive constructs and understanding. It is seen as the growth of a group identity that fosters social patterns unique to the group. The word "culture" is derived from a French term, which in turn derives from the Latin "colere," meaning to tend to the earth and grow, or cultivation and nurture. A number of tribes, ethnic and social groups in Africa have tremendous effects on the way the people think, relate, believe and do things. It may be a bit controversial, but behind some of the more outer causes of poverty in most African countries, lies in culture; the beliefs, ideologies and values that many Africans hold.

For example, many Africans think an easy going lifestyle or live now and don't make any plans for the future and they see it as the best way to live. While this may have some advantages, this stands often in the way of development and taking responsibility. Most notorious slum in these poor countries in Africa, many of slum inhabitants have mobile phones, despite the abject poverty there. Another striking fact is that many of these African citizens who are well off (very small wealthy class) do little to nothing to help their country forward. While they may help their own family and tribe through favouritism or even outright corruption, there is very little feeling of responsibility for the country and the whole population [5].

Again, religions make people in these countries concentrate in their spiritual wellbeing at the expense of wealth creation. People are not generally great believers in their capacities to alter their destiny, effort and talents. This result in slow down economic growth leading to unable to build a New Jerusalem in their world [6].

Geography looks at places and the relationships between people and their environments. It examines how human culture interacts with the natural environment and the way those locations and places can have an impact on people. This brings understanding of where things are found, why they are there, and how they develop and change over time.

Africans account for larger shares of those who live in poverty areas compared to Whites and non-Hispanics. Inhabitants of these countries live on less than $\$ 2$ a day and cannot meet their populations' expectations or manage these through their political processes (Figure 2).

The tropical location of the countries contribute poorly to agriculture as a result of poor nature of soil, photosynthesis, infestation

*Corresponding author: Julius Ofori Kwasi, Professor, Kwame Nkrumah University of Science and Technology, University in Kumasi, Ghana, Tel +233 -3220-60331; E-mail: julius2cee@yahoo.com

Received November 07, 2017; Accepted December 29, 2017; Published January 03, 2018

Citation: Kwasi JO (2018) Why Most African Countries are Poor. Arts Social Sci J 9: 317. doi: 10.4172/2151-6200.1000317

Copyright: (c) 2018 Kwasi JO. This is an open-access article distributed under the terms of the Creative Commons Attribution License, which permits unrestricted use, distribution, and reproduction in any medium, provided the original author and source are credited. 


\section{Mapping Africa's natural resources}

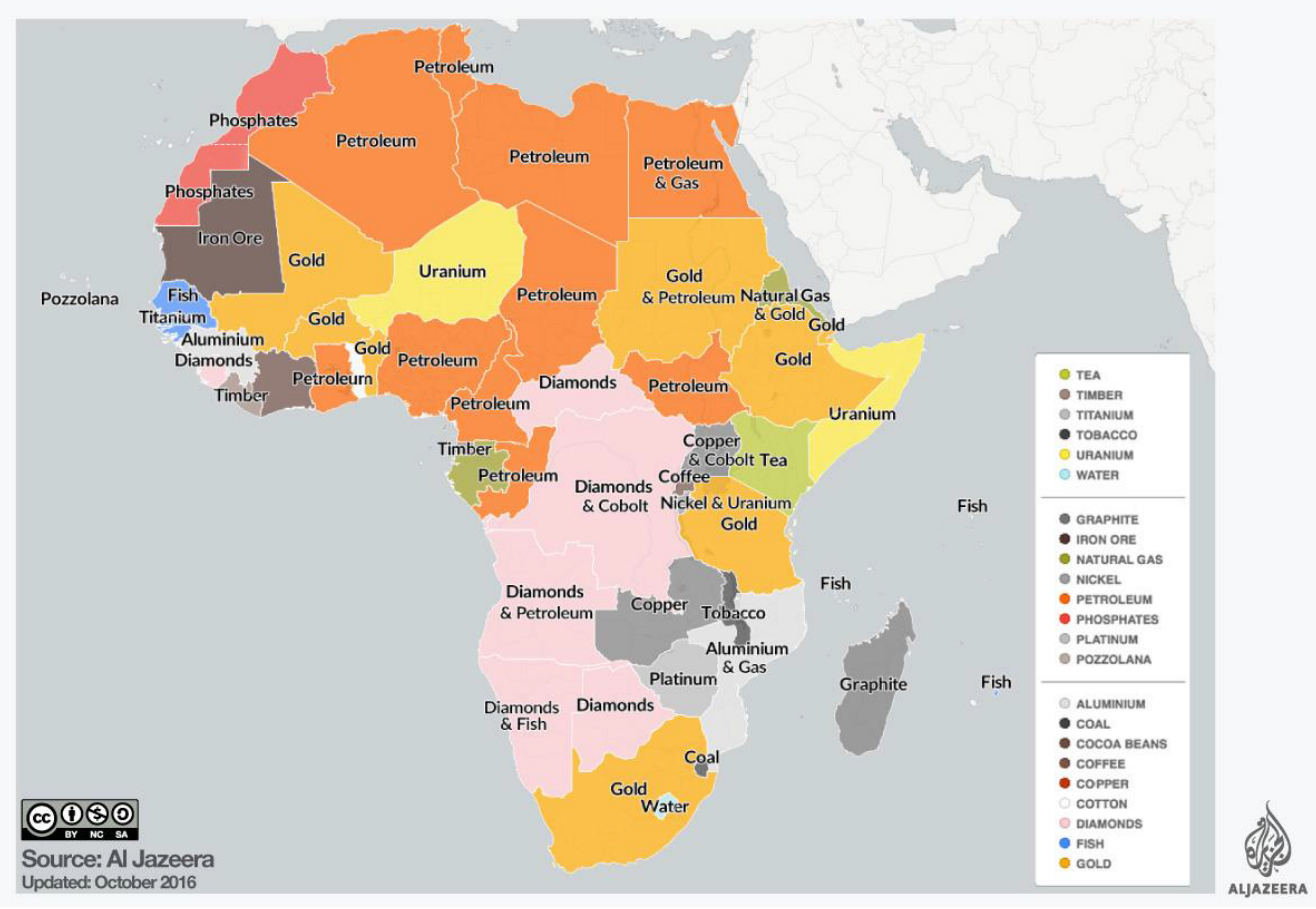

Figure 1: The mapping of Africa's natural resources.

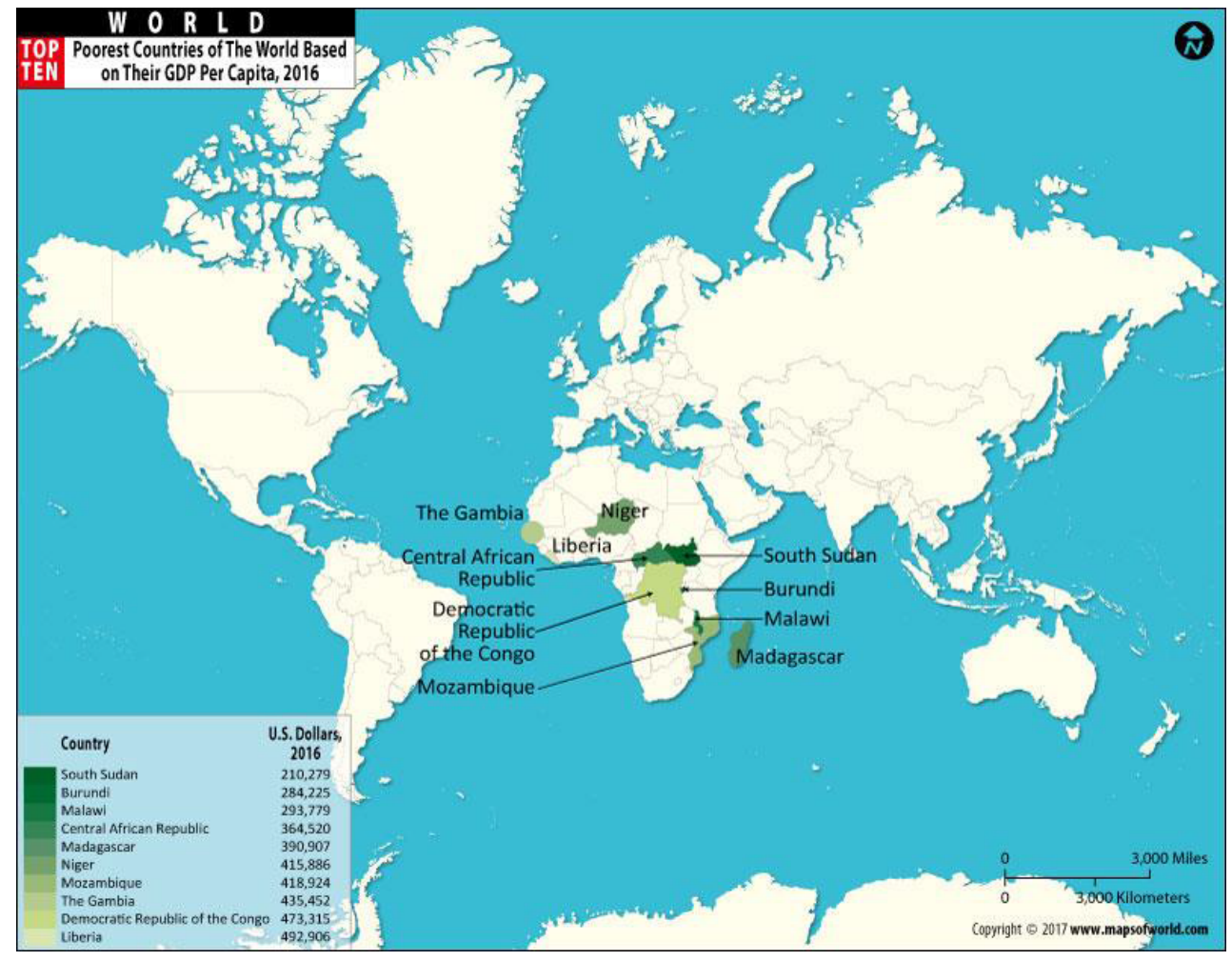

Figure 2: Some of the poorest African countries. 
of pests such as tsetse flies as well as influx of diseases( Parasitic diseases, Bacterial infections and Arboviruses) etc. People in these areas are prone to diseases which affect and influence productivity. Abundance of natural resources (such as oil, gold, timber, bauxite, diamond etc.) in these poor countries which economically refer as intensifiers make countries with good institutions richer and weak ones poorer resulting in resource trap, with country such Republic of Congo with abundant of Coltan found in every mobile phone with no exemption.

\section{Conclusion}

In conclusion, institutions are one of the major components of governance and internal lack of capacity within these institutions often leads to a lack of coordination among them. This leads to inefficient allocation of resources and often creates perverse incentives for unsustainable use. The governments of these countries should tend to be more proactive and accountable to their citizens. Also, these societies should be modest and sympathetic.

\section{References}

1. Goffrey M H (2006) Journal of Economic Issues.

2. Jepperson RL (1991) Institutions institutional effects and institutionalism. The New Institutionalism in Organizational Analysis 6: 143-163.

3. Bromley DW (1989) Economic Interests and Institutions: The Conceptual Foundations of Public Policy Blackwell Oxford 8: 303-311.

4. Collier P, Hoeffler A (2009) Testing the neocon agenda: Democracy in resource-rich societies European Economic Review 53 293-308.

5. Hatch MJ, Zilber T (2012) Conversation at the border between organization culture theory and institutional theory. Journal of Management Inquiry 21: 94-97.

6. James MG, Olsen JP (1995) Democratic governance. Free Press. 